IZA DP No. 6472

Is There Monopsonistic Discrimination against Immigrants? First Evidence from Linked Employer-Employee Data

Boris Hirsch

Elke J. Jahn

April 2012 


\title{
Is There Monopsonistic Discrimination against Immigrants? First Evidence from Linked Employer-Employee Data
}

\author{
Boris Hirsch \\ University of Erlangen-Nuremberg \\ Elke J. Jahn \\ IAB Nuremberg, \\ Aarhus University and IZA
}

Discussion Paper No. 6472

April 2012

IZA

P.O. Box 7240

53072 Bonn

Germany

Phone: +49-228-3894-0

Fax: +49-228-3894-180

E-mail: iza@iza.org

\begin{abstract}
Any opinions expressed here are those of the author(s) and not those of IZA. Research published in this series may include views on policy, but the institute itself takes no institutional policy positions.

The Institute for the Study of Labor (IZA) in Bonn is a local and virtual international research center and a place of communication between science, politics and business. IZA is an independent nonprofit organization supported by Deutsche Post Foundation. The center is associated with the University of Bonn and offers a stimulating research environment through its international network, workshops and conferences, data service, project support, research visits and doctoral program. IZA engages in (i) original and internationally competitive research in all fields of labor economics, (ii) development of policy concepts, and (iii) dissemination of research results and concepts to the interested public.
\end{abstract}

IZA Discussion Papers often represent preliminary work and are circulated to encourage discussion. Citation of such a paper should account for its provisional character. A revised version may be available directly from the author. 


\section{ABSTRACT \\ Is There Monopsonistic Discrimination against Immigrants? First Evidence from Linked Employer-Employee Data}

This paper investigates immigrants' and natives' labour supply to the firm within a semistructural approach based on a dynamic monopsony framework. Applying duration models to a large administrative employer-employee data set for Germany, we find that once accounting for unobserved worker heterogeneity immigrants supply labour less elastically to firms than natives. Under monopsonistic wage setting the estimated elasticity differential predicts a 4.7 log points wage penalty for immigrants thereby accounting for almost the entire unexplained native-immigrant wage differential of 2.9-5.9 log points. Our results imply that discriminating against immigrants is profitable rather than costly.

JEL Classification: J42, J61, J71

Keywords: monopsony, native-immigrant wage differential, discrimination, Germany

Corresponding author:

Elke J. Jahn

Institute for Employment Research (IAB)

Regensburger Strasse 104

90478 Nuremberg

Germany

E-mail: elke.jahn@iab.de 


\section{Introduction}

Just recently, there has been a growing number of both theoretical and empirical studies investigating the prevalence and causes of monopsony in the labour market (Ashenfelter et al., 2010; Manning, 2011). In contrast to the traditional literature on monopsony that saw monopsony power primarily as a consequence of labour markets characterised by demandside concentration or collusion, this "new" monopsony literature stresses that monopsony power may also be pervasive in labour markets consisting of many competing employers due to search frictions (e.g., Burdett and Mortensen, 1998; Manning, 2003a), mobility costs (e.g., Brueckner et al., 2002; Manning, 2003b), and heterogeneous preferences over non-wage job characteristics (e.g., Bhaskar and To, 1999; Booth and Coles, 2007).

Empirically, the question whether labour markets should be viewed as monopsonistic rather than competitive or whether the model of perfect competition is a sufficiently good approximation to real-world labour markets boils down to the question whether the labour supply curve to the single firm is horizontal or imperfectly elastic. There is a vivid recent empirical literature that tries to infer the firm-level labour supply elasticity either by exploiting natural experiments (Falch, 2010; Staiger et al., 2010) or by using a semi-structural estimation approach proposed by Manning (2003a), which builds on equilibrium search theory with wage posting (Ransom and Sims, 2010; Booth and Katic, 2011; Falch, 2011). In summary, this literature finds that the elasticity is far from infinite implying that employers possess substantial monopsony power, so that there is scope for marked deviations from the competitive wage. ${ }^{1}$

1 For a recent overview on this literature, see Manning (2011). 
Another strand of this "new" monopsony literature has also tried to assess whether monopsonistic discrimination, the roots of which originate in Robinson's (1933) seminal work applying third-degree price discrimination to the labour market, could be a fruitful framework to think about the gender pay gap as there are several reasons to consider women's labour supply to the firm as less elastic than men's. ${ }^{2}$ And indeed, a growing literature is emerging which finds that women's labour supply to the firm is less elastic than men's, so that monopsonistic discrimination may explain part of the unexplained gender pay gap in the data (Barth and Dale-Olsen, 2009; Hirsch et al., 2010; Ransom and Oaxaca, 2010).

Up to now, however, no attempt has been made to apply the insights of the "new" monopsony literature to native-immigrant wage differentials, perhaps on account of the immigration literature's main focus on questions of wage assimilation and labour market segmentation and less so on discrimination issues. Notably, there is no study investigating native-immigrant differences in firm-level labour supply elasticities, although there are several reasons, as will be discussed below, to presume that such differences exist and monopsonistic discrimination could contribute to the explanation of native-immigrant wage differentials. This paper is intended to fill this gap by estimating labour supply elasticity differentials for German and foreign males using rich administrative linked employeremployee data. In particular, we investigate whether a monopsonistic perspective may help understanding the German-foreign wage differential.

Focusing on Germany may be of particular interest as Germany is the third most popular destination for immigrants in the world after the U.S. and Russia (Freeman, 2006). Since the 1950s about 10.6 million people have immigrated to Germany. Although the net immigration rate to Germany has declined since the beginning of the millennium, in 2010 the

2 Note that the question whether women supply labour less elastically than men at the level of the firm should not be confused with the question whether women supply labour less elastically to the market. Whereas there is broad empirical evidence that women's labour supply is more elastic at the market level, this does not have to hold at the level of the firm, as is discussed in detail by Hirsch (2009). 
share of persons with foreign citizenship was still about 8.7 per cent.

Our main finding will be that foreigners show lower labour supply elasticities than Germans once worker unobserved heterogeneity is controlled for and also earn less than Germans controlling for different human capital endowments and workplace characteristics. Interestingly, the wage differential predicted from a dynamic monopsony model is of the same magnitude as the observed unexplained wage differential. Our reading of these results is that monopsonistic discrimination accounts for almost the entire unexplained German-foreign wage differential.

The remainder of this paper is organised as follows: Section 2 presents some theoretical considerations on possible reasons why native and immigrant workers may differ in their firm-level labour supply behaviour. Section 3 develops our econometric approach used to infer the labour supply elasticities from the data, and Section 4 presents our data set. Section 5 includes some descriptive evidence on job mobility and the immigrant wage gap in our sample, while Section 6 presents and discusses our empirical results on German and foreign workers' firm-level labour supply elasticities. Section 7 concludes.

\section{Theoretical Considerations}

In most countries, there exist significant native-immigrant wage differentials with immigrants' earnings being considerably lower than natives' (e.g., Kee, 1995; Nielsen et al., 2004; Elliot and Lindley, 2008; for Germany, e.g., Algan et al., 2010; Dustmann et al., 2010). One obvious reason for these differentials may be different endowments in human capital among groups: Immigrants and natives may, for instance, differ in their education levels and their occupations. In particular, immigrants may lack country-specific human capital upon arrival in their host country but catch up with natives' earnings over time as they acquire the missing 
country-specific skills. Following Chiswick (1978), a large literature has investigated whether there is such an assimilation process that reduces wage differences between immigrants and natives in the course of time spent in the host country. The general finding of this literature is that there are large initial wage differentials that tend to decline as immigrants spend time in the host country. Nonetheless, even after a long time in their host country immigrants still face lower wages than comparable natives (e.g., Borjas, 1999; Zimmermann, 2005).

Therefore, part of the native-immigrant wage differential may also reflect discrimination against immigrants not driven by different human capital endowments. First, employers, co-workers, or consumers may have prejudices against immigrants which may give rise to Beckerian (1971) taste-based discrimination. Second, employers may find it harder to assess the productivity of immigrants than the productivity of natives thus yielding a larger extent of statistical discrimination against immigrants (Phelps, 1972). And third, employers may possess more monopsony power over immigrant than over native workers and may therefore engage in monopsonistic discrimination against immigrants (Robinson, 1933).

Empirically, the scope of monopsonistic discrimination as an explanation of unexplained immigrant-native wage differentials leads to the question whether immigrant workers supply labour less elastically to firms than native workers. Put differently, the question is whether immigrants' labour supply to the firm is less driven by wages than natives'. As the "new" monopsony literature stresses, search frictions, mobility costs, and heterogeneous preferences over non-wage job characteristics are the main forces limiting the elasticity of workers' labour supply to employers. If we think of search frictions - as in the Burdett and Mortensen (1998) model - as a source of employers' monopsony power, immigrants may find it harder to climb the job ladder because they face more severe search frictions and thus end up with lower wages. For instance, immigrants may have a lower job finding rate because of limited command of the host country's language, limited knowledge on search channels, 
application routines and institutional details, or less extensive search networks. Moreover, there is empirical evidence of considerable workplace segregation of immigrants (Åslund and Skans, 2010; Dustmann et al., 2011) likely to limit their choice of employers. Finally, immigrants tend to form enclaves (e.g., Cutler et al., 2008; Granato and Kalter, 2009) which may also limit their regional mobility. All these factors are likely to impede immigrants' search activities and therefore should provide employers with additional monopsony power over immigrant workers. In line with these considerations, Hirsch (2010, pp. 168-173) finds that foreigners indeed face more severe search frictions than Germans.

That said there are also some reasons to conjecture immigrants to supply labour more elastically to firms than natives. If we think of horizontal job differentiation as one source of monopsony power, immigrants may have less pronounced preferences over non-wage job characteristics and may thus be more driven by pecuniary considerations than natives. For example, immigrants may be less attached to particular firm cultures and institutional details. Furthermore, immigrants typically experience substantial occupational downgrading when entering the host country's labour market (e.g., Chiswick et al., 2005; Constant and Massey, 2005) and may try to reduce their occupational mismatch by increased job shopping activities.

It is therefore unclear ex ante whether the elasticity-inhibiting or the elasticityenhancing factors dominate and whether monopsonistic discrimination may thus be viable. To assess whether monopsony may explain part of the native-immigrant wage differential empirically, we will in the following use a semi-structural estimation approach to infer the firm-level labour supply elasticity from workers' transition behaviour in the labour market.

\section{Econometric Approach}

The starting point of our econometric approach, which has been pioneered by Manning 
(2003a, pp. 96-104), is a simple dynamic monopsony model for the labour supply to the firm.

Consider a firm paying some wage $w$ at time $t$. We model the change in the labour supply to this firm $L(w)$ as

$$
\dot{L}(w)=R(w)-s(w) L(w)
$$

where $R(w)>0$ denotes the number of hires arriving at the firm at time $t$ with $R^{\prime}>0$ and $0<s(w)<1$ the separation rate with $s^{\prime}<0$. Accordingly, we assume that the firm can increase its labour supply by increasing its wage and that the labour supply adjusts sluggishly over time. Now consider a steady state with $\dot{L}(w)=0$. Then, we arrive at

$$
L(w)=R(w) / s(w)
$$

with $L^{\prime}>0 .{ }^{3}$ From (2) we get the long-run labour supply elasticity at the level of the firm $\varepsilon_{L w}$ as the difference of the wage elasticity of recruits $\varepsilon_{R w}$ and the wage elasticity of the separation rate $\varepsilon_{s w}$

$$
\varepsilon_{L w}=\varepsilon_{R w}-\varepsilon_{s w}
$$

Equation (3) further simplifies once we impose more structure on the model. Making use of Burdett and Mortensen's (1998) equilibrium search model of wage posting, which can be thought of as a dynamic general equilibrium model of monopsonistic competition, Manning demonstrates that $\varepsilon_{R w}=-\varepsilon_{S w}$, so that the supply elasticity becomes

$$
\varepsilon_{L w}=-2 \varepsilon_{s w}
$$

Intuitively, this holds because in this model one firm's wage-related hire is another firm's wage-related quit as transitions from and to non-employment are thought of as wage-inelastic.

3 Note that perfect competition is nested as the case with $L^{\prime} \rightarrow \infty$ due to $s^{\prime} \rightarrow-\infty$ and/or $R^{\prime} \rightarrow \infty$ at the competitive market wage that equalises labour supply and demand at the market level. 
Equation (4) would allow us to identify the firm-level labour supply elasticity by just estimating the separation rate elasticity and is the basis of the studies by Barth and Dale-Olsen (2009), Ransom and Oaxaca (2010), Ransom and Sims (2010), as well as Falch (2011).

Incorporating wage-elastic transitions from and to non-employment, for instance due to voluntary unemployment induced by welfare payments, Manning shows that the firm-level labour supply elasticity is given by the difference of a weighted average between the recruitment elasticities from employment and non-employment, $\varepsilon_{R w}^{e}$ and $\varepsilon_{R w}^{n}$, and the separation rate elasticities to employment and non-employment, $\varepsilon_{s w}^{e}$ and $\varepsilon_{s w}^{n}$,

$$
\varepsilon_{L w}=\theta_{R} \varepsilon_{R w}^{e}+\left(1-\theta_{R}\right) \varepsilon_{R w}^{n}-\theta_{s} \varepsilon_{s w}^{e}-\left(1-\theta_{s}\right) \varepsilon_{s w}^{n}
$$

with the weights being given by the share of recruits from employment $\theta_{R}$ and the share of separations to employment $\theta_{s}$, respectively. In a steady state, $\theta \equiv \theta_{R}=\theta_{S}$ holds. Allowing for stochastic job-to-job moves and adding more structure to the model, in particular by modelling the separation rates as proportional hazard models, Manning demonstrates that the long-run elasticity of the labour supply to the firm is given by

$$
\varepsilon_{L w}=-(1+\theta) \varepsilon_{s w}^{e}-(1-\theta)\left(\varepsilon_{s w}^{n}+\varepsilon_{\theta w}\right)
$$

where $\varepsilon_{\theta w}$ denotes the wage elasticity of the share of recruits hired from employment and, together with $\theta$, informs us on the recruitment function of the firm. ${ }^{4}$ This more general approach is adopted by Hirsch et al. (2010) and Booth and Katic (2011). To estimate the supply elasticity as given in equation (6), we have to estimate (i) the separation rate elasticity to employment $\varepsilon_{s w}^{e}$, (ii) the separation rate elasticity to non-employment $\varepsilon_{s w}^{n}$, (iii) the elasticity of the share of hires from employment $\varepsilon_{\theta w}$, and (iv) the share of hires from employment $\theta$.

The separation rate elasticities $\varepsilon_{s w}^{e}$ and $\varepsilon_{s w}^{n}$ are estimated from two proportional hazard

\footnotetext{
4 Note that the more simple approach as given by equation (4) is nested as $\varepsilon_{s w}^{n}, \varepsilon_{\theta w} \rightarrow 0$ and $\theta \rightarrow 1$.
} 
models for the instantaneous separation rates to employment and non-employment. We model the respective separation rate of job spell $i$ as a proportional hazard rate model

$$
s_{i}^{v}\left(t \mid \mathbf{x}_{i}^{v}(t), v_{i}^{v}(t)\right)=s_{0}^{v}(t) \exp \left(\mathbf{x}_{i}^{v}(t)^{\prime} \boldsymbol{\beta}^{v}\right) v_{i}^{v}(t)
$$

with $v=e, n$, baseline hazard $s_{0}^{v}(t)$, a vector of time-varying covariates $\mathbf{x}_{i}^{v}(t)$, a vector of coefficients $\boldsymbol{\beta}^{v}$ and (potentially time-varying) unobserved worker heterogeneity $v_{i}^{v}(t)$, where $t$ corresponds to the time since the start of the job spell, i.e. job tenure. Including the log wage as covariate its coefficient represents the respective separation rate elasticity $\varepsilon_{s w}^{v}{ }^{5}$

We should make clear that the inclusion of unobserved worker heterogeneity to the separation equations is of prime importance in this context as we have only few information on natives' and immigrants' socio-economic backgrounds, though these are likely to differ considerably. As a case in point, our data (for the details, see Section 4) do not contain information on immigrants' motivation or whether they are first- or second-generation immigrants brought up in Germany. We do not know either whether immigrants experienced occupational downgrading when entering the German labour market. All these factors may clearly affect immigrants' labour market transition behaviour and cause it to differ substantially from natives'. But they are only partly reflected in immigrants' observed characteristics, so that omitting unobserved worker heterogeneity is likely to cause severe bias in the estimated separation rate elasticities.

In the following analysis, we will consider two types of models: exponential models including Gamma frailties and stratified Cox models. In the exponential models, the baseline hazard $s_{0}^{\nu}(t)$ is assumed to be constant in job tenure and the unobserved heterogeneity $v_{i}^{v}(t)$ a time-constant worker random effect (frailty) that follows a Gamma distribution, as put for-

Assuming conditional independence of the separation probabilities to employment and non-employment Manning shows that they can be estimated separately by two independent hazard rate models. When estimating the separation rate to non-employment all job spells are used. When estimating the separation rate to employment, however, only those job spells that do not end in non-employment are considered. 
ward by Abbring and van den Berg (2007). This restricts the separation rate to show no duration dependence. In other words, there is no direct effect of job tenure on the separation rate. As argued by Manning (2003a, p. 103) this seems a sensible assumption as one of the key results of dynamic monopsony models à la Burdett and Mortensen (1998) giving rise to firm-level labour supply as in equation (1) is that firms raise wages to increase tenure and thus controlling for tenure would take away original variation from the wage variable.

Yet, in a random-effects approach covariates must not be correlated with unobserved worker heterogeneity. And this is unlikely to hold in our application since, for instance, natives and immigrants may have unobserved productivity differences not captured by, though correlated with standard human capital controls. To tackle this problem, we also make use of stratified Cox models in which the baseline hazard $s_{0}^{v}(t)$ is some arbitrary nonnegative function of job tenure as is the unobserved heterogeneity $v_{i}^{v}(t)$. Then adopting stratified partial likelihood estimation allows us to control for both the baseline hazard and the unobserved worker heterogeneity without the need of identifying them and thus to estimate the covariates' coefficients in a similarly convenient way as with the within estimator in linear fixed-effects models (cf. Ridder and Tunal1, 1999). It does so by resting the identification of $\boldsymbol{\beta}^{v}$ on within-variation at the worker level, that is, on multiple job spells per worker. Consequently, stratified Cox models allow us to go beyond the existing literature on monopsonistic gender discrimination, such as Barth and Dale-Olsen (2009), Hirsch et al. (2010), and Ransom and Oaxaca (2010), by taking account of unobserved worker heterogeneity that may be correlated with included covariates. While stratified partial likelihood estimation allows us to sweep out unobserved worker characteristics, using stratified Cox models comes at a price. Estimation forces us to control for job tenure as the worker-specific baseline hazard $s_{0}^{v}(t) v_{i}^{v}(t)$ in equation (7) drops out of the partial likelihood function without being constrained to be constant over job tenure. Thus, we expect the estimated separation rate elastic- 
ities as well as the resulting firm-level labour supply elasticities to be lower than in the exponential models as some variation in the separation probability is taken away from the wage variable and attributed to job tenure.

To estimate the wage elasticity of the share of recruits hired from employment $\varepsilon_{\theta w}$, we model the probability that a worker is hired from employment (as opposed to non-employment) as a logit model

$$
\operatorname{Pr}\left[y_{i}=1 \mid \mathbf{x}_{i}, v_{i}\right]=\Lambda\left(\mathbf{x}_{i}^{\prime} \boldsymbol{\beta}+v_{i}\right)
$$

where notation follows the same rules as before, $y_{i}$ is an indicator variable for a hire from employment, and $\Lambda$ denotes the c.d.f. of the standard-logistic distribution. Specifying $v_{i}$ as a normally distributed worker random effect we arrive at a random-effects logit model. Again, random-effects modelling requires unobserved heterogeneity $v_{i}$ to be independent of observed worker characteristics. To get rid of this problem, we also fit fixed-effects conditional logit models allowing unobserved worker heterogeneity to be related to observed characteristics. As can be easily shown, when including log wage as covariate in (8) its coefficient gives the wage elasticity of the share of recruits hired from employment $\varepsilon_{\theta w}$. The last thing to do is to estimate the share of recruits from employment $\theta$ from the data.

\section{Data}

To put this approach into practice, we need detailed data on job lengths, preceding and subsequent jobs and periods of non-employment, as well as on workers and employers over a long period of time as otherwise correcting for unobserved heterogeneity by either estimating random-effects or stratified proportional hazard models on the basis of multiple-spell data could not be done convincingly. For our purpose we combine two administrative data sets for 
the period 1985-2008: The Sample of Integrated Labour Market Biographies (SIAB) and the Establishment History Panel (BHP), both of which are provided by the Institute for Employment Research (IAB) of the German Federal Employment Agency.

The data on job lengths, transitions, and workers come from the SIAB, a 2 per cent random sample of all wage and salary employees registered with the German social security system during the period $1975-2008 .^{6}$ The data set is based on the notification procedure of the German social insurances that requires all employers to report information on their employees for the period they have been employed, but at least once at the end of a year. Since this information is used to calculate social security contributions, the data set is highly reliable and especially useful for analyses taking wages and job durations into account.

The data include, inter alia, information on the daily gross wage, on the employee's occupation, age, highest achieved education, sex, and nationality, on industry affiliation, on both worker and employer location, and on the start and end of each employee notification on a daily basis, thereby allowing us to use continuous time hazard rate modelling.

From 1992 onwards the SIAB also includes observations for East German workers. Restricting our analysis to the post-unification period would markedly reduce our period of observation and also add only few observations for immigrant workers as the wage and salary immigrant population in East Germany is negligible, viz. 2.2 per cent in 2008, while the share of wage and salary immigrants in West Germany amounts to 8 per cent (Federal Employment Agency, 2012). For this reason, we will focus our analysis throughout on individuals employed in West Germany (excluding Berlin) during the period 1985-2008.

In the following, we shall use job spells of male workers. Apart from obvious selection issues regarding female (immigrant) employment with low participation rates, the main reason for focussing on males is that female and male workers have been found to differ sig-

6 About 75 per cent of all people employed in Germany are covered by the social security system. For details about the data set, see Dorner et al. (2010). 
nificantly in their transition behaviours and, in particular, in their labour supply elasticities to the firm in Germany (Hirsch et al., 2010). Since our focus lies on the native-immigrant wage differential rather than the gender pay gap, considering male job spells seems sensible. As there is some empirical evidence of differences in the early retirement behaviour between German and immigrant men (Bonin et al., 2000), we further restrict our analysis to individuals aged of $18-55$.

The SIAB allows identifying foreigners only on the basis of citizenship. Due to the jus sanguinis tradition of the German law, naturalisation rates are traditionally very low (Brücker and Jahn, 2011), so that second-generation immigrants are still likely to possess foreign citizenship. To mitigate the possible effects of naturalisation, we classify all individuals as foreigners who are reported as foreign citizens in their first observation available.

Another important immigrant group in Germany consists of ethnic Germans, so-called Spätaussiedler. Since these receive German citizenship directly upon application, ethnic Germans are reported as Germans in our data. However, programs offered to ethnic Germans to facilitate their labour market integration, such as language courses and other integration subsidies, are reported in our data set. Using this information therefore allows us to identify the majority of ethnic Germans who have entered the German labour force. In 2008, about 3.6 per cent of all jobs were filled by ethnic Germans. Since ethnic Germans' labour market performance and language fluency resembles that of other foreigners (cf. Glitz, 2012), we classify them as foreigners.

The SIAB also includes unique plant identifiers that can be used to link it with the BHP. The BHP again consists of data from the notification procedure for the German social insurances that are this time aggregated at the plant level as of the 30th of June of a year (for details, see Spengler, 2008). It not only contains information on the plant's workforce composition like the numbers of female, skilled, foreign, or part-time workers in its 
workforce, and plant size, but also information on downsizing and plant closures. This is particularly important as we are aiming at identifying the impact of wages on individual workers' separation decisions. Without correcting for downsizing and closing plants, however, part of the measured effect of wages on separations and hirings may be demanddriven rather than a supply-side response and may for this reason not allow us to infer the firm-level labour supply elasticities from separation rate elasticities. To alleviate this problem, we exclude job spells in downsizing plants as well as in closing plants. For the very same reason, we also exclude job spells in plants with less than ten employees because these plants are not covered by the strict German employment protection legislation and also have a low likelihood of being covered by collective agreements and works councils, all of which are institutions hampering employers' ability to unilateraly dismiss workers. As jobs in the agricultual sector are often seasonal jobs, we exclude these job spells as well.

The data set resulting from linking the SIAB and the BHP allows us to build up an inflow sample of job spells starting between 1985 and 2008 taking into account workers' previous labour market status, the job length, and - provided the job ended during our period of observation - workers' subsequent labour market status. In the following, we follow our theoretical model and distinguish two labour market states: employment and non-employment. Consequently, a job may end with a transition to employment, which refers to a new job with another employer (i.e. a plant with a different plant identifyer), or with a transition to non-employment, which refers to a subsequent spell in registered unemployment or no spell in the data at all. The latter either implies that the individual has changed to non-employment without receiving UI benefits or that he has become, for instance, a self-employed not included in the data set. While our data do not enable us to disaggregate this category of unknown destination, information from other data sets suggests that the majority of employees in this 
category have indeed moved to non-employment. ${ }^{7}$

While information on job spells and daily gross wages included in the data are highly reliable, the data include no detailed information on the number of hours worked, and wages are also top-coded at the social security contribution ceiling, which affects 10.7 per cent of our observations. To deal with the first drawback, we restrict our analysis to full-time working individuals for whom daily gross wages are comparable. To cope with the second, we impute wages above the ceiling by imputing them using a heteroscedastic single imputation approach developed by Büttner and Rässler (2008) for this data set. ${ }^{8}$ Furthermore, information on workers' education is provided by employers. This means that educational levels are missing for 5.7 per cent of all observations in the final data set. To alleviate this problem, we impute the missing information on education by employing a procedure proposed by Fitzenberger et al. (2006) that allows inconsistent education information to be corrected. After applying this imputation procedure, only about 1.3 per cent of the job spells in our final data are dropped due to missing or inconsistent information on education.

\section{Descriptive Evidence}

Our final sample consists of 621,185 job spells belonging to 240,902 German workers and 125,489 spells belonging to 51,385 foreign workers. (For descriptive statistics on key variables, see the Appendix Table.) Table 1, which gives an overview of the transitions between employment and non-employment, makes clear that Germans and foreigners show rather

7 See, for example, Bartelheimer and Wieck (2005) for a transition matrix between employment and nonemployment based on the German Socio-Economic Panel, which allows stratification of the "unknown" category into detailed categories.

8 Note that including imputed wages as covariates in the hazard rate and logit models may introduce some bias in estimated wage elasticities. As a robustness check we repeated all estimations excluding all those job spells with top-coded wages. The results were virtually identical to those including imputed wages, so that we conclude that our results are not driven by the imputation mechanism and are valid in this respect. 
different transition patterns both with respect to hirings and to separations: First, Germans are less likely to be hired from non-employment with a share of hires from non-employment of 58 per cent than foreigners whose share amounts to 70 per cent. This can be seen as a first indication that foreigners face more severe search frictions because the share of hires from non-employment can serve as a simple measure of (on-the-job) search frictions in the labour market (see Manning, 2003a, pp. 44-49). ${ }^{9}$ Intuitively, the share gives a simple measure on the difficulities to climb the job ladder by wage-increasing job shopping activities. Second, foreigners are relatively more likely to exit existing jobs to non-employment than employment (with separation rates to employment and non-employment of 54.4 and 25.8 per cent, respectively) compared to Germans (with separation rates to employment and non-employment of 46.2 and 34.7 per cent, respectively). Again, this may reflect differences in search frictions as separations to employment are more likely to reflect voluntary job-to-job moves as a means of achieving better-paying jobs and reducing job mismatch. ${ }^{10}$

\section{- TABLE 1 ABOUT HERE -}

Turning to wages, we find a large average raw German-foreign wage differential of $20 \log$ points (see the Appendix Table). In the next step, we run some standard wage regressions controlling for several worker and plant characteristics to arrive at an estimate of the unexplained wage differential in our sample. In these estimations, we include seven age, three education, eleven occupation, and seven job tenure dummies as socio-economic varia-

9 Note that the same result also shows up when controlling for worker and plant characteristics by estimating a logit model for the probability that a recruit is hired from non-employment. Still, the probability is significantly higher for foreign as opposed to German workers which is in line with the findings discussed in Section 2.

10 Note that our data set does not allow us to distinguish between voluntary quits and involuntary dismissals. A crude approximation, which is in line with empirical evidence from other German data sets (see, e.g., Burda and Mertens, 2001), would be that job-to-job moves are predominantly voluntary quits more likely to yield wage increases and occupational upgrading, whereas most of the separations to non-employment may be involuntary dismissals. 
bles. As plant controls we include four plant size dummies, the shares of foreign, part-time, high-skilled, low-skilled, and female workers in the plant's workforce, the median age of the plant's workers, three dummies for the size of the region the firm is located at (i.e. rural, urban, and metropolitan), and 25 sector dummies. Estimations also include year dummies and the regional unemployment rate at the municipality level. Running this regression, the results of which are shown in the left column of Table 2, yields an average unexplained Germanforeign wage differential of $5.9 \log$ points, which is highly significant.

\section{- TABLE 2 ABOUT HERE -}

To come closer to the within-job wage differential which is usually seen as the preferred measure of wage discrimination, we also run a wage regression including job cellspecific effects (i.e. fixed effects for any filled occupation-plant cell), where we all in all distinguish 322,297 job cells in our sample. While this decreases the unexplained differential by half, it is still highly significant and amounts to $2.9 \mathrm{log}$ points (see the right column in Table 2). Note that by comparison to other unexplained wage differentials in the German labour market like the unexplained gender pay gap these numbers are rather modest, though in line with the existing literature on unexplained native-immigrant wage differentials (e.g., Diekmann et al., 1993; Velling, 1995; Beblo et al., 2011; Lehmer and Ludsteck, 2011). ${ }^{11}$

\section{Results}

To estimate labour supply elasticities at the firm level for both foreigners and Germans,

11 There are also studies finding no unexplained native-immigrant wage differential (Lang, 2005) or even that immigrants are paid better, ceteris paribus, than natives (Mavromaras, 2004), although the overall picture is that modest unexplained native-immigrant are present in the German labour market. 
thereby assessing whether monopsonistic discrimination may provide an explanation of the German-foreign wage differential in our sample, we use the econometric approach discussed in Section 3. We estimate proportional hazard rate models for the instantaneous separation rates to employment and non-employment and logit models for the probability that a worker is hired from employment separately for Germans and foreigners. Including the job's log wage in these estimations we arrive at estimates of the separation rate elasticities to employment and non-employment as well as the wage elasticity of the share of hires from employment. We can then plug these numbers into equation (6) to arrive at an estimate of the firmlevel labour supply elasticity.

With the exception of the job tenure dummies, we include in all estimations the same covariates (listed in the notes to Table 3 ) as in the wage regressions and treat them as timevarying. In particular, we include eleven occupation dummies. Controlling for occupations is important due to occupational downgrading of foreigners likely to be negatively correlated with wages but positively with the separation probability. Omitting occupations in the estimations would therefore inflate the wage effect in the separation equations and thus bias the estimated separation elasticity upwards (in absolute value). Furthermore, including variables capturing the plant's workforce composition, like the share of foreign or high-skilled and low-skilled workers, is important due to possible workplace segregation of foreigners.

In a first step, we model the separation equations as exponential models including worker frailties and fit random-effects logit models, the results of which are shown in the left column of Table 3. In the exponential models, the estimated separation rate elasticity to employment is slightly larger (in absolute value) for foreigners than for Germans, while the opposite holds for the estimated separation rate elasticity to non-employment. Moreover, the share of hires from employment is less wage-elastic for foreigners, thereby reducing the supply elasticity differential between foreigners and Germans. Note that, except in the case of 
the separation rate elasticity to employment, the 95 per cent confidence intervals of the estimates for foreigners and Germans do not overlap, so that the elasticity differences can be regarded as statistically significant. Plugging estimates into equation (6) we find that foreigners and Germans do not differ in their firm-level labour supply elasticities with elasticities being estimated as 2.626 for foreigners and 2.589 for Germans. ${ }^{12}$

\section{- TABLE 3 ABOUT HERE -}

However, we have little confidence that adding random effects to the hazard rate and logit models allows us to take account of unobserved worker heterogeneity, as the inclusion of random effects constrains unobserved factors to be independent of observed covariates. Controlling for unobserved influences, though, is crucial in this particular setting as we know little on immigrants apart from standard variables capturing human capital differences such as education, age, and occupation. For this reason, assuming unobserved factors to be unrelated with observed characteristics is far-fetched in our eyes. To address unobserved worker heterogeneity more convincingly, we estimate stratified Cox and conditional logit models. While stratified partial likelihood estimation allows us to sweep out unobserved characteristics, estimation forces us to control for job tenure taking away variation from the wage variable and attributing it to job length. We should therefore expect the estimates of the separation and firm-level labour supply elasticities to be lower than the previous random-effects estimates. And indeed estimated separation and supply elasticities following from stratified partial likelihood estimation are considerably lower than those from the exponential models (see the right column in Table 3). Interestingly, all elasticities, the separation rate elasticities to employment and non-employment, the elasticity of the share of hires from employment,

12 Note that the magnitude of these estimates is quite similar to those for males presented by Hirsch et al. (2010) who use similar German linked employer-employee data, though for a much shorter period of time (2000-2002). 
and the resulting firm-level labour supply elasticity, are now lower (in absolute value) for foreigners than for Germans. While for the separation rate elasticity to employment the 95 per cent confidence intervals of the estimates for foreigners and Germans overlap, the other two elasticities also differ significantly. The estimated firm-level labour supply elasticity is now smaller for foreigners than for Germans, the estimates being 1.875 for Germans but only 1.644 for foreigners. Since we regard controlling for unobserved worker heterogeneity as essential in this setting and the random-effects assumption likely to be violated, this presents our preferred specification.

To assess the economic relevance of the estimated German-foreign firm-level supply elasticity differential, we use the fact that in a simple (dynamic) model of monopsony a worker's wage is given by

$$
w=\frac{\varepsilon_{L w}}{1+\varepsilon_{L w}} \phi
$$

where $\phi$ denotes the worker's marginal revenue product and $\varepsilon_{L w}$ the long-run firm-level labour supply elasticity. ${ }^{13}$ Consider now foreigners and Germans with the same marginal revenue product $\phi$ but different elasticities $\varepsilon_{L w}^{f}$ and $\varepsilon_{L w}^{g}$, where the superscripts $f$ and $g$ refer to foreign and German workers, respectively. Assuming the same productivity across workers is plausible as we have controlled for both standard human capital variables and unobserved worker heterogeneity in our stratified Cox and conditional logit estimations. Then the German-foreign wage differential following from equation (9) is

$$
\ln w^{f}-\ln w^{g} \approx \frac{w^{f}-w^{g}}{w^{g}}=\frac{\varepsilon_{L w}^{f}-\varepsilon_{L w}^{g}}{\varepsilon_{L w}^{g}\left(\varepsilon_{L w}^{f}+1\right)}
$$

Applying equation (10) to the results of our preferred specification we find that estimated

13 To derive equation (9) in a dynamic monopsony model, we have to assume that firms maximise steady-state profits and discount future profits at a negligible rate. 
elasticity differentials imply a ceteris paribus earnings disadvantage for foreigners of roughly $4.7 \log$ points. Interestingly, this number is very close to the unexplained German-foreign wage differential in our sample amounting to $2.9-5.9 \log$ points depending on whether jobcell fixed effects are included. Our reading of these results is that almost the entire unexplained differential can be accounted for by monopsonistic discrimination with the less elastic group of foreign workers receiving lower wages than comparable German workers.

\section{Conclusions}

In this paper, we have investigated the firm-level labour supply elasticity for male Germans and foreigners within a semi-structural estimation approach based on a dynamic monopsony model. In our preferred specification addressing unobserved worker heterogeneity by stratified partial likelihood and conditional logit estimators, we find that foreigners supply labour less elastically to the firm compared to Germans. Estimated supply elasticities are about 1.9 for Germans but only 1.6 for foreigners.

Under monopsonistic wage setting this elasticity differential would imply $4.7 \mathrm{log}$ points lower wages for foreigners, ceteris paribus. Interestingly, the observed Germanforeign unexplained wage differential in our sample amounts to 2.9-5.9 log points depending on specification and therefore is very close to the differential arising under monopsonistic discrimination. Put differently, the whole observed differential would be due to monopsonistic discrimination if employers were to use their different monopsony power over their German and foreign workers. Following Robinson (1933, p. 224), who argued that "just as we have price discrimination for a monopolist, so we may have price discrimination for a monopsonist," we therefore conclude that differences in firm-level labour supply elasticities between German and foreign workers can account for most of the observed unexplained wage 
differential. Other than Becker's (1971) taste-based discrimination, this sort of monopsonistic discrimination is profit-increasing and thus fostered by market forces in the long run. What is more, monopsonistic discrimination does not force us to introduce (arbitrary) assumptions on individuals' preferences. As Stigler and Becker (1971, p. 89) argue, "no significant behavior has been illuminated by assumptions of differences in tastes. Instead, they ... have been a convenient crutch to lean on when the analysis has bogged down. They give the appearance of considered judgement, yet really have only been ad hoc arguments that disguise analytical failures." For this reason, monopsonistic discrimination does not only seem to be a more coherent theoretical framework to think about immigrant wage discrimination, but also offers straightforward policy implications how to remove it. Under monopsonistic discrimination employers discriminate against foreign workers because it is profitable to do so. Stopping them from doing so would "just" require the policy-maker to remove the sources of foreigners' lower firm-level labour supply elasticity, for instance by mitigating search frictions through providing better skills on the host country's language, institutions, and labour market to immigrants. On the other hand, removing clichés and racism, forming discriminatory preferences against immigrants seems to be a much harder and less obvious job.

An open question that could not be investigated here is why foreigners are less driven by pecuniary considerations than natives. Although we argued that more severe search frictions as well as lower regional mobility due to search networks, the forming of enclaves, and occupational segregation may provide explanations for this finding, empirical analyses on this issue are missing but prospective. We should also stress that "it does not follow that differences in supply elasticities necessarily generate differences in wages," (Hirsch and Schumacher, 2005, p. 987) as employers may be constrained to make use of their monopsony power, for instance, by labour market institutions such as collective bargaining and works councils. Future research should therefore investigate whether differences in monopsony 
power really cause differences in wages, rather than just comparing these two as has be done in this paper. If this causal link could be established, the case of monopsonistic discrimination against immigrants could be made even more vigorously.

\section{References}

Abbring, J.H. and van den Berg, G.J. (2007), "The unobserved heterogeneity distribution in duration analysis," Biometrika, 94(1): 87-99

Algan, Y., Dustmann, C., Glitz, A., and Manning, A. (2010), "The economic situation of first and second-generation immigrants in France, Germany and the United Kingdom," Economic Journal, 120(542): F4-F30

Ashenfelter, O.C., Farber, H., and Ransom, M.R. (2010), "Labor market monopsony," Journal of Labor Economics, 28(2): 203-210

Åslund, O. and Skans, O.N. (2010), "Will I see you at work? Ethnic workplace segregation in Sweden, 1985-2002," Industrial and Labor Relations Review, 63(3): 471-493

Bartelheimer, P. and Wieck, M. (2005), "Arbeitslosigkeit und Unterbeschäftigung", in Soziologisches Forschungsinstitut, Institut für Arbeitsmarkt- und Berufsforschung, Institut für Sozialwissenschaftliche Forschung, and Internationales Institut für empirische Sozialökonomie (eds.), Berichterstattung zur sozioökonomischen Entwicklung in Deutschland - Arbeit und Lebensweisen. Erster Bericht, pp. 271-302, Wiesbaden: VS Verlag für Sozialwissenschaften

Barth, E. and Dale-Olsen, H. (2009), "Monopsonistic discrimination, worker turnover, and the gender wage gap," Labour Economics, 16(5): 589-597

Beblo, M., Ohlert, C., and Wolf, E. (2011), Ethnic Wage Inequality within Firms: An Analysis with German Linked Employer-Employee Data, Berlin: mimeo

Becker, G.S. (1971), The Economics of Discrimination, Chicago, IL: Chicago University Press, 2nd ed.

Bhaskar, V. and To, T. (1999), "Minimum wages for Ronald McDonald monopsonies: A theory of monopsonistic competition," Economic Journal, 109(455): 190-203

Bonin, H., Raffelhüschen, B. and Walliser, J. (2000), "Can immigration alleviate the demographic burden?" FinanzArchiv, 57(1): 1-21

Borjas, G.J. (1999), "The economic analysis of immigration," in O.C. Ashenfelter and D.E. Card (eds.), Handbook of Labor Economics, vol. 3A, pp. 1697-1760, Amsterdam: Elsevier

Booth, A.L. and Coles, M.G. (2007), "A microfoundation for increasing returns in human capital accumulation and the under-participation trap," European Economic Review, 51(7): 1661-1681

Booth, A.L. and Katic, P. (2011), "Estimating the wage elasticity of labour supply to a firm: What evidence is there for monopsony?" Economic Record, 87(278): 359-369

Brücker, H. and Jahn, E.J. (2011), "Migration and wage-setting: Reassessing the labor market effects of migration," Scandinavian Journal of Economics, 113(2): 286-317

Brueckner, J.K., Thisse, J.-F., and Zenou, Y. (2002), "Local labor markets, job matching, and urban location," International Economic Review, 43(1): 155-171 
Burda, M.C. and Mertens, A. (2001), "Estimating wage losses of displaced workers in Germany," Labour Economics, 8(1):15-41

Burdett, K. and Mortensen, D.T. (1998), "Wage differentials, employer size, and unemployment," International Economic Review, 39(2): 257-273

Büttner, T. and Rässler, S. (2008), "Multiple imputation of right-censored wages in the German IAB Employment Register considering heteroscedasticity," in Federal Committee on Statistical Methodology (FCSM) Research Conference 2007, Arlington, VA: FCSM

Chiswick, B.R. (1978) "The effect of Americanization on the earnings of foreign-born men", Journal of Political Economy 86(5): 81-87

Chiswick, B.R., Lee, Y.L., and Miller, P.W. (2005), "A longitudinal analysis of immigrant occupational mobility: A test of the immigrant assimilation hypothesis," International Migration Review, 39(2): 332-353

Constant, A. and Massey, D.S. (2005), "Labor market segmentation and the earnings of German guestworkers," Population Research and Policy Review, 24(5): 489-512

Cutler, D.M., Glaeser, E.L., and Vigdor, J.L. (2008), "When are ghettos bad? Lessons from immigrant segregation in the United States," Journal of Urban Economics, 63(3): 759774

Diekmann, A., Engelhardt, H., and Hartmann, P. (1993), "Einkommensungleichheit in der Bundesrepublik Deutschland: Diskriminierung von Frauen und Ausländern?" Mitteilungen aus der Arbeitsmarkt- und Berufsforschung (Journal of Labour Market Research), 26(3): 386-398

Dorner, M., Heining, J., Jacobebbinghaus, P., and Seth, S. (2010), "The Sample of Integrated Labour Market Biographies," Schmollers Jahrbuch (Journal of Applied Social Science Studies), 130(4): 599-608

Dustmann, C., Glitz, A., and Schönberg, U. (2011), Referral-based Job Search Networks, IZA discussion paper no. 5777, Bonn: Institute for the Study of Labor

Dustmann, C., Glitz, A., and Vogel, T. (2010), "Employment, wages, and the economic cycle: Differences between immigrants and natives," European Economic Review, 54(1): 1-17

Elliot, R.J.R. and Lindley, J.K. (2008), "Immigrant wage differentials, ethnicity and occupational segregation," Journal of the Royal Statistical Society (Series A), 171(3): 645-671

Falch, T. (2010), "The elasticity of labor supply at the establishment level," Journal of Labor Economics, 28(2): 237-266

Falch, T. (2011), "Teacher mobility responses to wage changes: Evidence from a quasinatural experiment," American Economic Review (Papers and Proceedings), 101(3): $460-465$

Federal Employment Agency (2012), Arbeitsmarkt in Zahlen - Beschäftigungsstatistik, Sozialversicherungspflichtig Beschäftigte nach Staatsangehörigkeiten und Geschlecht, Nürnberg: Federal Employment Agency

Fitzenberger, B., Osikominu, A., and Völter, R. (2006), "Imputation rules to improve the education variable in the IAB Employment Subsample," Schmollers Jahrbuch (Journal of Applied Social Science Studies), 126(3): 405-436

Freeman, R.B. (2006), "People flows in globalization," Journal of Economic Perspectives, 20(2): $22-44$

Glitz, A. (2012), "The labor market impact of immigration: A quasi-experiment exploiting immigrant location rules in Germany," Journal of Labor Economics, 30(1): 175-213

Granato, N. and Kalter, F. (2009), "Regional concentration and labour market success: Endogenous and exogenous effects of relative minority group size," Kölner Zeitschrift für Soziologie und Sozialpsychologie, 61(3): 387-409 
Hirsch, B. (2009), "The gender pay gap under duopsony: Joan Robinson meets Harold Hotelling," Scottish Journal of Political Economy, 56(5): 543-558

Hirsch, B. (2010), Monopsonistic Labour Markets and the Gender Pay Gap: Theory and Empirical Evidence, Berlin: Springer

Hirsch, B., Schank, T., and Schnabel, C. (2010), "Differences in labor supply to monopsonistic firms and the gender pay gap: An empirical analysis using linked employeremployee data from Germany," Journal of Labor Economics, 28(2): 291-330

Hirsch, B.T. and Schumacher, E.J. (2005), "Classic or new monopsony? Searching for evidence in nursing labor markets," Journal of Health Economics, 24(5): 969-989

Kee, P. (1995), "Native-immigrant wage differentials in the Netherlands: Discrimination?" Oxford Economic Papers, 47(2): 302-317

Lang, G. (2005), "The difference between wages and wage potentials: Earnings disadvantages of immigrants in Germany," Journal of Economic Inequality, 3(1): 12-42

Lehmer, F. and Ludsteck, J. (2001), "The immigrant wage gap in Germany: Are East Europeans worse off?" International Migration Review, 45(4): 872-906

Manning, A. (2003a), Monopsony in Motion: Imperfect Competition in Labor Markets, Princeton, NJ: Princeton University Press

Manning, A. (2003b), "The real thin theory: Monopsony in modern labour markets," Labour Economics, 10(2): 105-131

Manning, A. (2011), "Imperfect competition in the labor market," in O.C. Ashenfelter and D.E. Card (eds.), Handbook of Labor Economics, vol. 4B, pp. 973-1041, Amsterdam: Elsevier

Mavromaras, K.G. (2004), "Wage differentials between male-female and native-foreign workers in pre-unification Germany," International Journal of Manpower, 25(3/4): 300-320

Nielsen, H.S., Rosholm, M., Smith, N., and Husted, L. (2004), "Qualifications, discrimination, or assimilation? An extended framework for analysing immigrant wage gaps," Empirical Economics, 29(4): 855-883

Phelps, E.S. (1972), "The statistical theory of racism and sexism," American Economic Review, 62(4): 659-661

Ransom, M.R. and Oaxaca, R.L. (2010), "New market power models and sex differences in pay," Journal of Labor Economics, 28(2): 267-289

Ransom, M.R. and Sims, D.P. (2010), "Estimating the firm's labor supply curve in a "new monopsony' framework: Schoolteachers in Missouri," Journal of Labor Economics, 28(2): 331-355

Ridder, G. and Tunalı, İ (1999), "Stratified partial likelihood estimation," Journal of Econometrics, 92(2): 193-232

Robinson, J.V. (1933), The Economics of Imperfect Competition, London: MacMillan

Spengler, A. (2008), "The Establishment History Panel," Schmollers Jahrbuch (Journal of Applied Social Science Studies), 128(3): 501-509

Staiger, D.O., Spetz, J., and Phibbs, C.S. (2010), "Is there monopsony power in the labor market? Evidence from a natural experiment," Journal of Labor Economics, 28(2): 211-236

Stigler, G.J. and Becker, G.S. (1977), "De gustibus non est disputandum," American Economic Review, 67(2): 76-90

Velling, J. (1995), Wage Discrimination and Occupational Segregation of Foreign Male Workers in Germany, ZEW discussion paper no. 95-04, Mannheim: Centre for European Economic Research

Zimmermann, K.F. (2005), European Migration: What Do We Know? Oxford: Oxford University Press 
Table 1: Transitions

\begin{tabular}{|c|c|c|}
\hline & Germans & Foreigners \\
\hline Job spells & 621,185 & 125,489 \\
\hline Hires from employment & $261,442 \quad(42.0)$ & $37,243 \quad(29.6)$ \\
\hline Hires from nonemployment & $359,743(58.0)$ & $88,246 \quad(70.4)$ \\
\hline Separations to employment & 215,270 & $32,349 \quad(25.8)$ \\
\hline Separations to nonemployment & $286,765(46.2)$ & $68,310(54.4)$ \\
\hline Right-censored job spells & $119,150(19.2)$ & $24,830(19.8)$ \\
\hline Workers & 240,902 & 51,385 \\
\hline Plants & 184,495 & 29,628 \\
\hline
\end{tabular}

Notes: The data sets used are the SIAB, 1985-2008, and the BHP, waves 1985-2008. Percentages are shown in brackets. 


\begin{tabular}{|c|c|c|}
\hline & $\begin{array}{l}\text { w/o job-cell } \\
\text { fixed effects }\end{array}$ & $\begin{array}{l}\text { with job-cell } \\
\text { fixed effects }\end{array}$ \\
\hline Foreigner (dummy) & $-0.059(0.001)$ & $-0.029(0.001)$ \\
\hline \multicolumn{3}{|l|}{ Low-skilled (reference group) } \\
\hline Medium-skilled (dummy) & $0.074(0.002)$ & $0.044(0.001)$ \\
\hline High-skilled (dummy) & $0.220(0.003)$ & $0.153(0.003)$ \\
\hline Age 18-25 years (dummy) & $-0.099(0.001)$ & $-0.070(0.001)$ \\
\hline \multicolumn{3}{|l|}{ Age 26-30 years (reference group) } \\
\hline Age $31-35$ years (dummy) & $0.070(0.001)$ & $0.055(0.001)$ \\
\hline Age 36-40 years (dummy) & $0.109(0.001)$ & $0.086(0.001)$ \\
\hline Age $40-45$ years (dummy) & $0.125(0.001)$ & $0.101 \quad(0.001)$ \\
\hline Age 46-50 years (dummy) & $0.122(0.001)$ & $0.101 \quad(0.001)$ \\
\hline Age $51-55$ years (dummy) & $0.109(0.002)$ & $0.087(0.002)$ \\
\hline \multicolumn{3}{|l|}{ Tenure under 1 year (reference group) } \\
\hline Tenure $1-5$ years (dummy) & $0.113(0.001)$ & $0.067(0.001)$ \\
\hline Tenure 6-10 years (dummy) & $0.162(0.001)$ & $0.105(0.001)$ \\
\hline Tenure $11-15$ years (dummy) & $0.187(0.002)$ & $0.132(0.002)$ \\
\hline Tenure 16-20 years (dummy) & $0.212(0.003)$ & $0.153(0.003)$ \\
\hline Tenure more than 20 years (dummy) & $0.243(0.005)$ & $0.179(0.005)$ \\
\hline \multicolumn{3}{|l|}{ Plant size 11-50 (reference group) } \\
\hline Plant size 51-200 (dummy) & $0.028(0.001)$ & $-0.007(0.001)$ \\
\hline Plant size 201-1,000 (dummy) & $0.081 \quad(0.002)$ & $-0.012(0.002)$ \\
\hline Plant size more than 1,000 (dummy) & $0.123(0.004)$ & $-0.004(0.004)$ \\
\hline Share of foreign workers & $-0.052(0.007)$ & $0.038 \quad(0.009)$ \\
\hline Share of female workers & $-0.147(0.005)$ & $-0.105(0.008)$ \\
\hline Share of part-time workers & $-0.034(0.006)$ & $0.021 \quad(0.008)$ \\
\hline Share of high-skilled workers & $0.276(0.008)$ & $0.139(0.012)$ \\
\hline Share of low-skilled workers & $-0.129(0.004)$ & $-0.043(0.005)$ \\
\hline Median age of workers at the plant & $-0.007(0.000)$ & $-0.002(0.000)$ \\
\hline Regional unemployment rate & $-0.007(0.000)$ & $0.001 \quad(0.000)$ \\
\hline Constant & $4.031 \quad(0.010)$ & $4.289 \quad(0.007)$ \\
\hline Observations & $2,596,848$ & $2,596,848$ \\
\hline Job cells & - & 322,297 \\
\hline$R^{2}$ & 0.552 & 0.851 \\
\hline
\end{tabular}

Notes: The data sets used are the SIAB, 1985-2008, and the BHP, waves 1985-2008. The regressand is the daily gross log wage. Standard errors clustered at the plant level are given in parentheses. Further regressors included are 11 occupation dummies, three dummies for the size of the region the firm is located at, 25 sector, and 24 year dummies. 
Table 3: Estimated firm-level labour supply elasticities and implied foreign-German pay gaps

\begin{tabular}{|c|c|c|c|c|}
\hline & \multicolumn{2}{|c|}{$\begin{array}{l}\text { Exponential/logit models } \\
\text { with worker random effects }\end{array}$} & \multicolumn{2}{|c|}{$\begin{array}{l}\text { Stratified Cox/conditional logit models } \\
\text { with worker fixed effects }\end{array}$} \\
\hline & Germans & Foreigners & Germans & Foreigners \\
\hline Separation rate elasticity to employment $\left(\hat{\varepsilon}_{s w}^{e}\right)$ & $\begin{array}{c}-1.649 \\
(0.010) \\
{[-1.669,-1.630]}\end{array}$ & $\begin{array}{c}-1.706 \\
(0.024) \\
{[-1.754,-1.658]}\end{array}$ & $\begin{array}{c}-1.399 \\
(0.019) \\
{[-1.436,-1.361]}\end{array}$ & $\begin{array}{c}-1.335 \\
(0.050) \\
{[-1.433,-1.236]}\end{array}$ \\
\hline Separation rate elasticity to nonemployment $\left(\hat{\varepsilon}_{s w}^{n}\right)$ & $\begin{array}{c}-1.977 \\
(0.007) \\
{[-1.991,-1.962]}\end{array}$ & $\begin{array}{c}-1.754 \\
(0.016) \\
{[-1.783,-1.722]}\end{array}$ & $\begin{array}{c}-0.990 \\
(0.012) \\
{[-1.012,-0.967]}\end{array}$ & $\begin{array}{c}-0.855 \\
(0.024) \\
{[-0.902,-0.808]}\end{array}$ \\
\hline $\begin{array}{l}\text { Wage elasticity of the share of recruits hired from } \\
\text { employment }\left(\hat{\varepsilon}_{\theta w}\right)\end{array}$ & $\begin{array}{c}1.552 \\
(0.011) \\
{[1.530,1.575]}\end{array}$ & $\begin{array}{c}1.165 \\
(0.026) \\
{[1.114,1.216]}\end{array}$ & $\begin{array}{c}1.184 \\
(0.016) \\
{[1.152,1.216]}\end{array}$ & $\begin{array}{c}0.978 \\
(0.037) \\
{[0.906,1.051]}\end{array}$ \\
\hline Share of hires from employment $(\hat{\theta})$ & 0.421 & 0.297 & 0.421 & 0.297 \\
\hline Firm-level labour supply elasticity $\left(\hat{\varepsilon}_{L w}\right)$ & 2.589 & 2.626 & 1.875 & 1.644 \\
\hline Implied foreign-German pay gap $\left(\ln w^{\widehat{f}-\ln } w^{g}\right)$ & \multicolumn{2}{|c|}{0.004} & \multicolumn{2}{|c|}{-0.047} \\
\hline
\end{tabular}

Notes: The data sets used are the SIAB, 1985-2008, and the BHP, waves 1985-2008. Standard errors are shown in parentheses, 95 per cent confidence intervals in squared brackets. Covariates included in the estimations are three education, seven age, four plant size, 11 occupation, 25 sector, 24 year, and three dummies for the size of the region the plant is located at, the shares of part-time, high-skilled, low-skilled, female and foreign workers in the plant's workforce, the median age of the plant's workforce, and the regional unemployment rate at the municipality level. 
Appendix Table: Selected Descriptive Statistics (Means)

\begin{tabular}{|c|c|c|}
\hline & Germans & Foreigners \\
\hline Log daily gross wage $(€)$ & 4.470 & 4.270 \\
\hline Low-skilled (dummy) & 0.085 & 0.361 \\
\hline Medium-skilled (dummy) & 0.784 & 0.591 \\
\hline High-skilled (dummy) & 0.132 & 0.048 \\
\hline Age (years) & 35.1 & 35.5 \\
\hline Age $18-25$ years (dummy) & 0.163 & 0.159 \\
\hline Age $26-30$ years (dummy) & 0.185 & 0.178 \\
\hline Age $31-35$ years (dummy) & 0.191 & 0.185 \\
\hline Age $36-40$ years (dummy) & 0.175 & 0.165 \\
\hline Age $40-45$ years (dummy) & 0.138 & 0.144 \\
\hline Age $46-50$ years (dummy) & 0.098 & 0.111 \\
\hline Age $51-55$ years (dummy) & 0.051 & 0.058 \\
\hline Tenure (years) & 2.690 & 2.220 \\
\hline Tenure under 1 year (reference group) & 0.514 & 0.582 \\
\hline Tenure $1-4$ years (dummy) & 0.289 & 0.259 \\
\hline Tenure 5-10 years (dummy) & 0.130 & 0.109 \\
\hline Tenure $11-15$ years (dummy) & 0.047 & 0.038 \\
\hline Tenure $16-20$ years (dummy) & 0.017 & 0.011 \\
\hline Tenure more than 20 years (dummy) & 0.002 & 0.001 \\
\hline Plant size & 1,251 & 1,153 \\
\hline Plant size $11-50$ (dummy) & 0.277 & 0.261 \\
\hline Plant size 51-200 (dummy) & 0.296 & 0.320 \\
\hline Plant size $201-1,000$ (dummy) & 0.261 & 0.262 \\
\hline Plant size more than 1,000 (dummy) & 0.166 & 0.157 \\
\hline Share of foreign workers & 0.083 & 0.195 \\
\hline Share of female workers & 0.278 & 0.242 \\
\hline Share of high-skilled workers & 0.085 & 0.055 \\
\hline Share of low-skilled workers & 0.211 & 0.316 \\
\hline Share of part-time workers & 0.111 & 0.093 \\
\hline Median age of workers at the plant & 37.7 & 37.4 \\
\hline Regional unemployment rate & 8.710 & 8.400 \\
\hline Observations & $2,193,645$ & 403,203 \\
\hline Job spells & 621,185 & 125,489 \\
\hline Workers & 240,902 & 51,385 \\
\hline Plants & 184,495 & 29,628 \\
\hline
\end{tabular}

Notes: The data sets used are the SIAB, 1985-2008, and the BHP, waves 1985-2008. 